\title{
SELECTED ELEMENTS OF THE MANAGEMENT OF PRODUCTION PROCESSES
}

\author{
Szymon Mitkow ${ }^{1}$ (D), Ewa Sterniczuk²
}

Military University of Technology, Faculty of Logistics, Urbanowicza 2 Str., 00-908 Warsaw, Poland; e-mail: szymon.mitkow@wat.edu.pl, safro88@gmail.com; ORCID ID: 10000-0003-2845-2589, 20000-0001-6483-7422

\begin{abstract}
The effectiveness and efficiency of production system is a guarantee of the company's success, especially in times of dynamic growth of trade (including online trade), as well as increasing customers' requirements, who want to have goods always available and delivered, preferably on the day of order. A modern customer of services raises the bar high not only for production systems, but also for transport systems. Therefore, IT tools supporting the management process of all areas of its activity are implemented in enterprises. This article describes selected of them, focusing primarily on the support of production planning process.

As the use of IT systems should be preceded by deepening the knowledge of algorithms applied in them, first of all a calculation example of the use of material requirements planning procedure for complex products with a modular structure was presented, and then the characteristics of selected IT tools supporting the processes of material requirements planning and enterprise resource planning have been made.
\end{abstract}

Key words:

production planning, resource management, material requirement planning.

Research article

(C) 2019 Szymon Mitkow, Ewa Sterniczuk This is an open access article licensed under the Creative Commons Attribution-NonCommercial-NoDerivatives 4.0 license (http://creativecommons.org/licenses/by-nc-nd/4.0/) 


\section{INTRODUCTION}

The announced revolution 4.0 has made the market economy and logistics face significant challenges, primarily defined by the changing and constantly growing needs of the client. The effective adaptation to consumer requirements is foremost determined by the ability to personalize the offer, as well as the ability to meet the needs tailored to the client's needs. The rapid development of e-commerce and ever-shortening delivery times are a test for the flexibility and agility of logistics systems, including production process management.

Therefore, parallel to the higher expectations of consumers, IT systems are developing to support the functioning of enterprises, especially manufacturing ones, which must be ready to satisfy the diverse needs of clients, taking into account their size and deadline for completing the order. Support for these operations are planning and control tools, facilitating decision making in the aspect of supplying materials and raw materials necessary for production in a way that guarantees continuity and assumed production intensity, and minimizing production inventory in progress [13].

Obviously, distribution systems are also developing at a similar rate, in addition to organizational aspects, the readiness of transport means is emphasized $[6,9]$. It is also worth stressing that these changes most concern civilian enterprises, but many technologies and tools are also implied in organizational units of the budget sphere, such as ambulance services, fire brigades [4], distribution systems operating at Military Economic Branches [5, 20], or aviation bases [3, 7]. In such organizations, the readiness and efficiency of systems is particularly desirable, since human life and health may depend on its level.

This article presents one of the tools commonly used in production to facilitate planning material needs. In companies, they operate in the form of computer programs that make calculations for complex production processes, taking into account all material resources of the company, raw materials as well as materials, components, semi-finished products, etc. However, according to the authors, using extensive MRP (material requirement planning) and ERP systems (enterprise resource planning) should be preceded by the knowledge of the algorithms used and the calculations performed. Therefore, the article focuses on the presentation of the methodology for calculating the demand for the supply of materials and elements necessary to produce the final product and delivery dates, in accordance with the MRP concept. 


\section{MATERIAL REQUIREMENT PLANNING (MRP)}

The task of MRP class systems is planning activities covering all stages of production and assembly of the final product, taking into account its structure, external orders, available inventory, the volume of 'pending' inventory and fixed production times of individual elements, their assembly or deliveries. The result of the calculations is the production schedule defining the delivery dates of materials and elements necessary to produce the final product, in accordance with the dependent demand resulting from the prioritized production plan.

The genesis of the system is the MRP I system developed in 1957 by APICS (called American Production and Inventory Control Society), which works best in the conditions of unit production, serial production as well as in the case of assembly or flow production, when the demand for products is dependent, irregular [14]. In the simplest terms, its task is to determine what materials or components, in what quantity and on what date should be needed, on the one hand to minimize the state of inventory, and on the other to ensure continuity of production. MRP I works with a pressing system (push). Production tasks result from the production plan determined on the basis of customer orders and sales forecasts, which may result in an increased level of final inventories. Among the main objectives of MRP I should be mentioned [14]:

- synchronization of ordering and delivery processes of materials and components with production needs;

- enhanced control of individual production stages;

- precise specification of delivery times of raw materials and semi-finished products;

- planning and controlling stocks and ensuring the supply of the necessary goods once are used or beforehand;

- reduction of material and operational stocks;

- activating/strengthening the relationship between the buyer and the supplier in order to jointly plan needs;

- the ability to react faster to potential changes, such as stock shortage, breakdowns, stoppages of the production line, delays in deliveries;

- precise determination of production costs;

- more efficient use of owned infrastructure.

In other words, the MRP system consists of the three elements, which include: input information (demand according to the main production schedule, inventory of materials and components and finished products), MRP program and output 
information (gross and net demand for materials and components needed for production and delivery dates). The scheme of MRP system operation is shown in fig. 1.

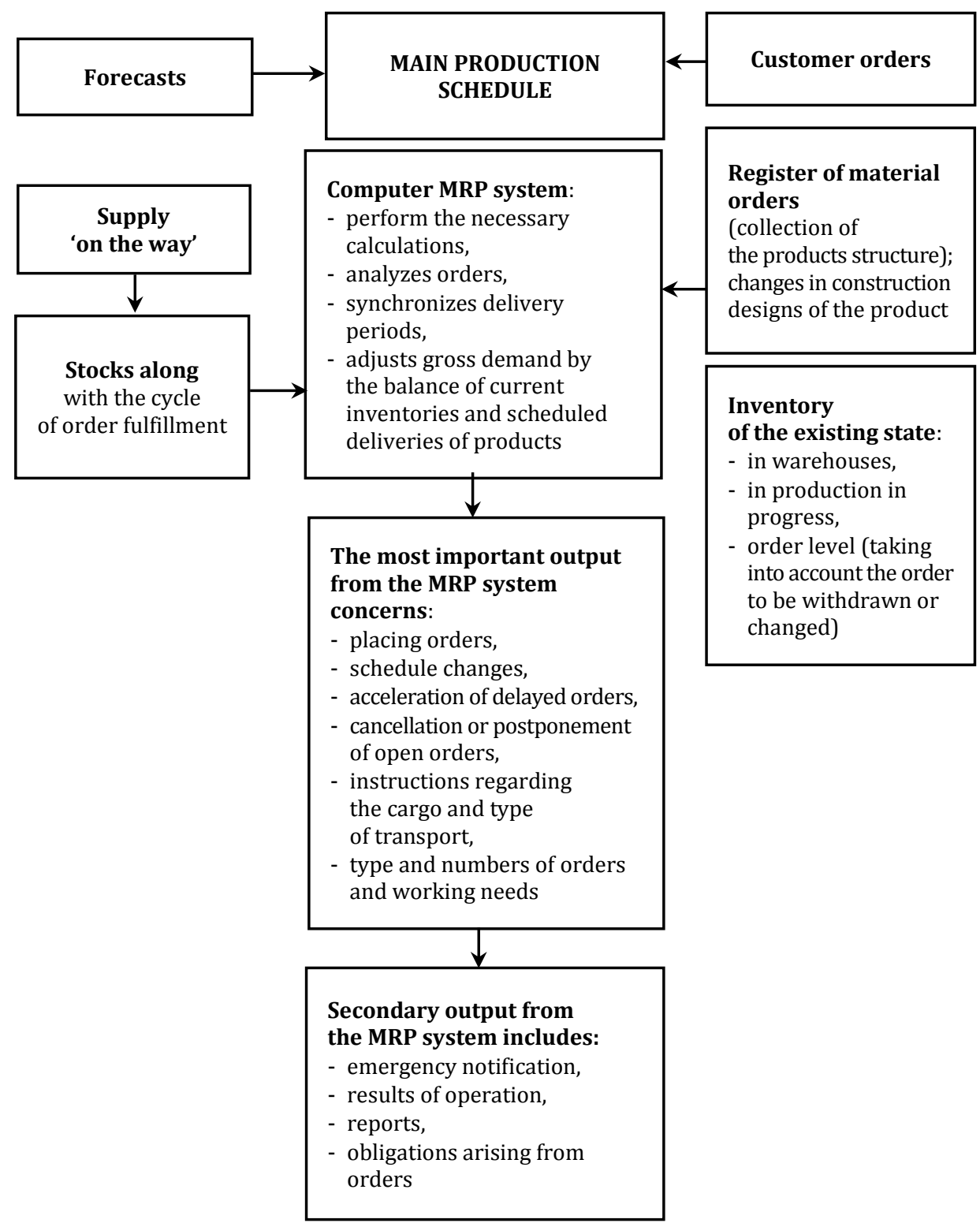

Fig. 1. Elements of the MRP system [14] 
The main advantages of the MRP I system include [12]:

- the possibility of minimizing or completely reducing stocks;

- development of production schedules taking into account both the actual demand and the forecasted;

- supporting processes for managing the flows of raw materials, materials, components, semi-finished products and finished products;

- maximizing production capacity;

- the possibility of planning the company's long-term development;

- coordination of activities within the internal logistics of the enterprise and in the supply chain;

- ongoing control and quick response to disruptions in deliveries;

- precise matching of orders to incoming customers' needs;

- the ability to control production (acceleration and delaying the process).

Among the disadvantages of the MRP system are listed [12]: the need for computerization, difficulties in introducing changes in the enterprise, increase in transport costs resulting from stock minimization, as well as lack of sensitivity to short-term demand fluctuations.

\section{PLANNING OF MRP II PRODUCTION INVENTORY}

The development of MRP I (which primarily focused on storage space) for other areas of the company's operations constitutes the MRP II system. It includes not only materials needed for production, but also all company resources, including fixed assets, capital and human resources. It also contains spheres associated with the preparation and planning of production processes, sales and distribution of finished products. It is able to take into account the classification of $A B C$, distinguish between dependent and independent demand, and has the ability to prioritize production orders. The extensive MRP II concept (fig. 2) requires the use of IT support, therefore, as in the case of MRP I, dedicated software was created to implement it in the enterprise. Nevertheless, the basis is the material requirement planning algorithm, which will be presented later in the article. 


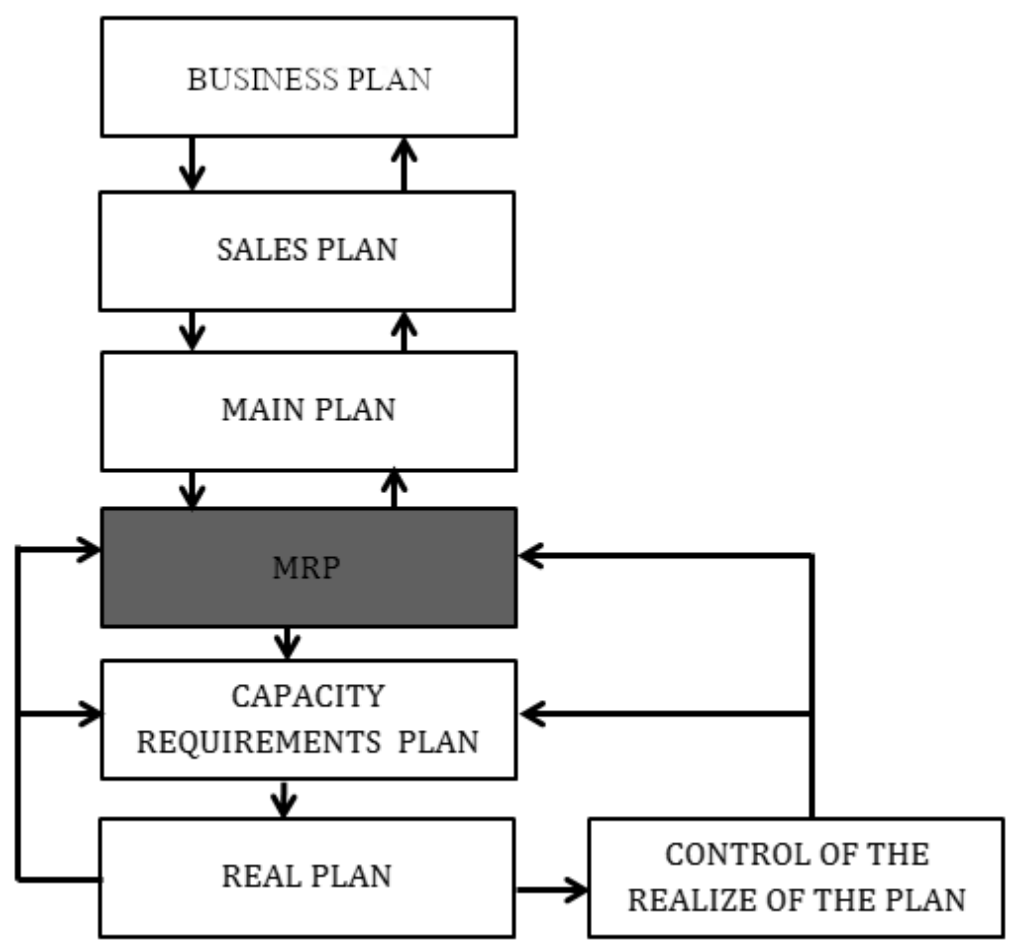

Fig. 2. Overall MRP II scheme [1]

\section{THE EXAMPLE OF MRP PROCEDURE USE}

Produced products often consist of many different, sometimes repetitive elements. This is particularly true for the electronics, automotive or shipbuilding industry [10], thus the presented example below will concern the MRP procedure for a product with a complex - modular structure, consisting of three products: A, B and $\mathrm{C}$.

The starting point of the calculations is the master production plan (tab. 1), which defines the demand for all products, semi-finished products, elements, etc. and provides information on available resources (materials, production capacity).

The next step is to determine the level of inventory that the company has at its disposal as well as the time of order completion if the available resources prove to be insufficient (tab. 2). 
Tab. 1. Main schedule of production

\begin{tabular}{|c|c|c|c|c|}
\hline \multirow{2}{*}{$\begin{array}{c}\text { Product/ } \\
\text { intermediate/ } \\
\text { element }\end{array}$} & \multicolumn{5}{|c|}{ Week } \\
\cline { 2 - 5 } & $\mathbf{1 0}$ & $\mathbf{1 1}$ & $\mathbf{1 2}$ & $\mathbf{1 3}$ \\
\hline A & 90 & - & - & 100 \\
\hline B & 75 & - & - & 80 \\
\hline C & 60 & - & - & 75 \\
\hline D & 25 & - & - & 60 \\
\hline E & - & - & - & 35 \\
\hline F & 10 & - & - & 45 \\
\hline G & 90 & - & - & 70 \\
\hline H & 55 & - & - & - \\
\hline I & - & - & - & 45 \\
\hline J & - & - & - & 30 \\
\hline K & 50 & - & - & 55 \\
\hline L & 10 & - & - & - \\
\hline
\end{tabular}

Tab. 2. Available inventory stocked up by delivery time

\begin{tabular}{|c|c|c|}
\hline $\begin{array}{c}\text { Product/ } \\
\text { intermediate/ } \\
\text { element }\end{array}$ & Inventory in 1 week & $\begin{array}{c}\text { Delivery time } \\
\text { (week) }\end{array}$ \\
\hline A & 30 & 3 \\
\hline B & 15 & 3 \\
\hline C & 40 & 3 \\
\hline D & 45 & 2 \\
\hline E & 25 & 2 \\
\hline F & 10 & 2 \\
\hline G & 65 & 1 \\
\hline H & 80 & 1 \\
\hline I & 30 & 1 \\
\hline J & 25 & 1 \\
\hline K & 0 & 1 \\
\hline L & 0 & 1 \\
\hline
\end{tabular}

The final stage is the analysis of the product structure on the basis of which, using back planning, a material list is created. The modular structure of products A, B and $C$ is shown in fig. 1-3. At each of the highlighted levels, more modules/ elements appear, they are:

- level 1- module D;

- level 2- module E;

- level 3- module F;

$1(216) 2019$ 
- level 4- module G;

- level 5 - individual elements.

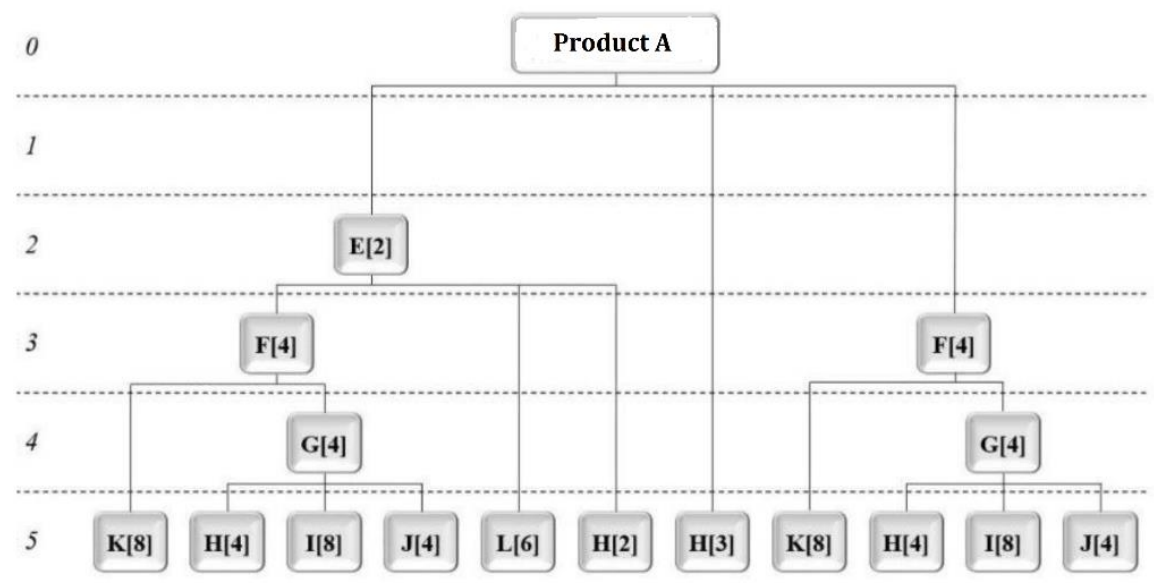

Fig. 3. Modular structure of product A

The analysis of product structure A (fig. 3) shows that it consists of two types of modules ( 2 modules $\mathrm{E}$ and 4 modules $\mathrm{F}$ ) and 3 elements $\mathrm{H}$. The modules $\mathrm{E}$ and $\mathrm{F}$, respectively, consist of:

- module $\mathrm{E}$ - two modules $\mathrm{F}$, three elements $\mathrm{L}$ and one element $\mathrm{H}$;

- module F - one module G, two elements K.

In the same way, the remaining products should be analyzed, ie B and C.

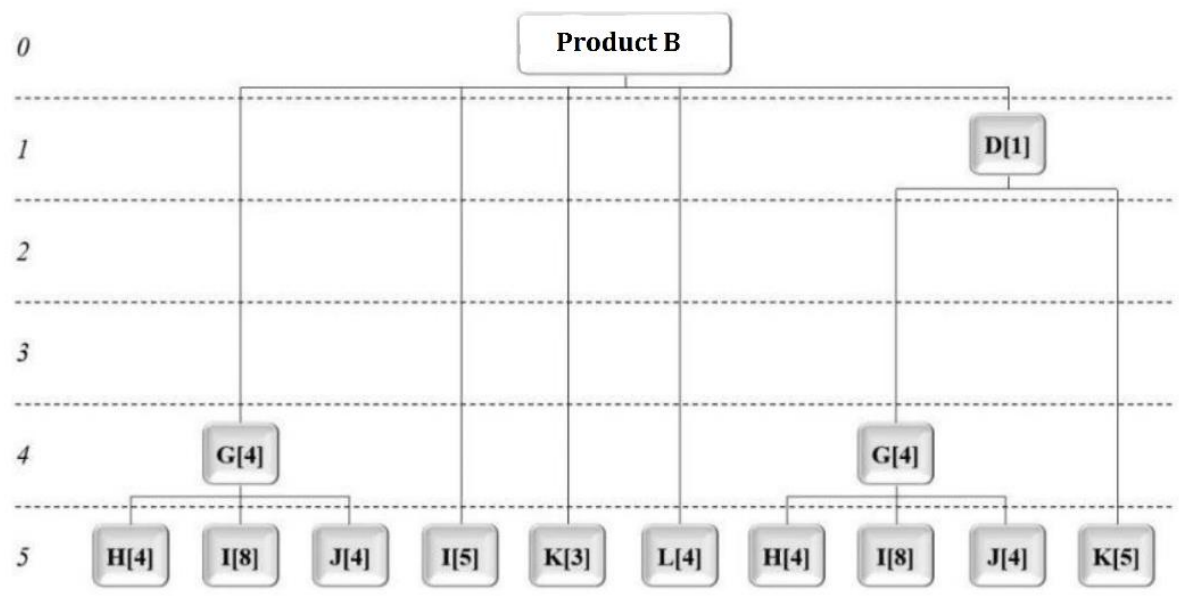

Fig. 4. Modular structure of product B 


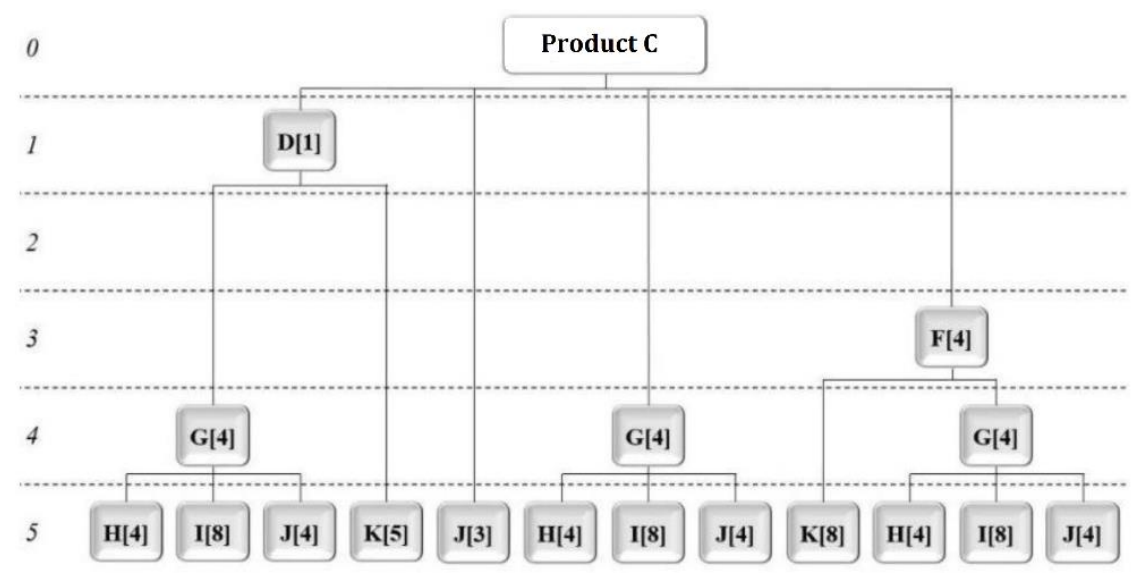

Fig. 5. Modular structure of product C

Using the knowledge about the structure of products, calculation of the gross demand for components and elements in particular weeks is made. The first step is the division into independent products, i.e. those that are not elements of the structure of other products, and dependent, composed of other elements. Products A, B and $\mathrm{C}$ are independent products, whereas D, E, F, G, H, I and J - dependent, which can be presented in the following abbreviated way, including components for individual elements and their numerical relations:

- A, B, C - independent products;

- $D(1 \mathrm{~B}, 1 \mathrm{C})$ - a module included in products $\mathrm{B}$ and $\mathrm{C}$ - one module for each;

- E (2A);

- $\mathrm{F}(4 \mathrm{~A}, 4 \mathrm{C}, 2 \mathrm{E})$;

- $\mathrm{G}(4 \mathrm{~B}, 4 \mathrm{C}, 4 \mathrm{D}, 1 \mathrm{~F})$;

- $\mathrm{H}(3 \mathrm{~A}, 1 \mathrm{E}, 1 \mathrm{G})$;

- I (5B, 2G);

- J $(3 \mathrm{C}, 1 \mathrm{G})$;

- $\mathrm{K}(3 \mathrm{~B}, 5 \mathrm{D}, 2 \mathrm{~F})$;

- L (4B, 3E).

The next step is to draw up a production and delivery schedule for the products A, B and C mentioned above, modules D, E and F and elements G, H, I and J (tab. 3-5). The calculation scheme will be presented based on the first demand for module $D$, resulting from the need to manufacture products $\mathrm{A}, \mathrm{B}$ and $\mathrm{C}$, which is a component. In the 10th week, production (gross demand) of 90 pieces of product $A$ and 75 pieces of product $B$ and 60 items of product $C$ (tab. 1) is planned. Because there is a stock 
of 30 pieces of product A, 15 pieces of product B and 40 items of product C (tab. 2), the resources should be taken into account first. In this way, we obtain a net demand, which is: for product A and B for 60 items, and for product C for 20 items (tab. 3). Because the delivery time is 3 weeks in both cases, the order must be placed in week 7. The analyzed product D is needed only for the production of product $B$ and $\mathrm{C}$. One product $\mathrm{D}$ will be required for each of these products, therefore the gross demand for product $\mathrm{D}$ will be the total of net needs for product $\mathrm{B}$ and $\mathrm{C}$ submitted in week 7 and will amount to 80 items (tab. 3). However, since the company has at its disposal 25 items of finished product $\mathrm{D}$, after taking this stock into account, we have net needs for product D of 35. Due to the two-week waiting period, the order should be submitted in the 5 th week.

The same should be done for the remaining weeks and products. The calculations for all components are presented in tab. 1-3.

Tab. 3. Schedule for delivery of products A, B, C, D

\begin{tabular}{|c|c|c|c|c|c|c|c|c|c|c|c|c|c|c|}
\hline \multirow{2}{*}{ Product } & \multirow{2}{*}{ Specification } & \multicolumn{13}{|c|}{ Week } \\
\hline & & 1 & 2 & 3 & 4 & 5 & 6 & 7 & 8 & 9 & 10 & 11 & 12 & 13 \\
\hline \multirow{5}{*}{ A } & Gross requirements & & & & & & & & & & 90 & & & 100 \\
\hline & Projected on hand & 30 & 30 & 30 & 30 & 30 & 30 & 30 & 30 & 30 & 30 & 0 & 0 & 0 \\
\hline & Net requirements & & & & & & & & & & 60 & & & 100 \\
\hline & Planned order receipts & & & & & & & & & & 60 & & & 100 \\
\hline & $\begin{array}{l}\text { Planned order } \\
\text { released }\end{array}$ & & & & & & & 60 & & & 100 & & & \\
\hline \multirow{5}{*}{ B } & Gross requirements & & & & & & & & & & 75 & & & 80 \\
\hline & Projected on hand & 15 & 15 & 15 & 15 & 15 & 15 & 15 & 15 & 15 & 15 & 0 & 0 & 0 \\
\hline & Net requirements & & & & & & & & & & 60 & & & 80 \\
\hline & Planned order receipts & & & & & & & & & & 60 & & & 80 \\
\hline & $\begin{array}{l}\text { Planned order } \\
\text { released }\end{array}$ & & & & & & & 60 & & & 80 & & & \\
\hline \multirow{5}{*}{$\mathrm{C}$} & Gross requirements & & & & & & & & & & 60 & & & 75 \\
\hline & Projected on hand & 40 & 40 & 40 & 40 & 40 & 40 & 40 & 40 & 40 & 40 & 0 & 0 & 0 \\
\hline & Net requirements & & & & & & & & & & 20 & & & 75 \\
\hline & Planned order receipts & & & & & & & & & & 20 & & & 75 \\
\hline & $\begin{array}{l}\text { Planned order } \\
\text { released }\end{array}$ & & & & & & & 20 & & & 75 & & & \\
\hline \multirow{5}{*}{$\mathrm{D}$} & Gross requirements & & & & & & & 80 & & & 180 & & & 60 \\
\hline & Projected on hand & 45 & 45 & 45 & 45 & 45 & 45 & 45 & 0 & 0 & 0 & 0 & 0 & 0 \\
\hline & Net requirements & & & & & & & 35 & & & 180 & & & 60 \\
\hline & Planned order receipts & & & & & & & 35 & & & 180 & & & 60 \\
\hline & $\begin{array}{l}\text { Planned order } \\
\text { released }\end{array}$ & & & & & 35 & & & 180 & & & 60 & & \\
\hline
\end{tabular}


Tab. 4. Schedule for delivery of products E, F, G, H

\begin{tabular}{|c|c|c|c|c|c|c|c|c|c|c|c|c|c|c|}
\hline \multirow{2}{*}{ 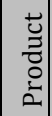 } & \multirow{2}{*}{ Specification } & \multicolumn{13}{|c|}{ Week } \\
\hline & & 1 & 2 & 3 & 4 & 5 & 6 & 7 & 8 & 9 & 10 & 11 & 12 & 13 \\
\hline \multirow{5}{*}{$\mathrm{E}$} & Gross requirements & & & & & & & 120 & & & 200 & & & 35 \\
\hline & Projected on hand & 25 & 25 & 25 & 25 & 25 & 25 & 25 & 0 & 0 & 0 & 0 & 0 & 0 \\
\hline & Net requirements & & & & & & & 95 & & & 200 & & & 35 \\
\hline & $\begin{array}{l}\text { Planned order } \\
\text { receipts }\end{array}$ & & & & & & & 95 & & & 200 & & & 35 \\
\hline & $\begin{array}{l}\text { Planned order } \\
\text { released }\end{array}$ & & & & & 95 & & & 200 & & & 35 & & \\
\hline \multirow{5}{*}{$\mathrm{F}$} & Gross requirements & & & & & 190 & & 320 & 400 & & 710 & 70 & & 45 \\
\hline & Projected on hand & 10 & 10 & 10 & 10 & 10 & 0 & 0 & 0 & 0 & 0 & 0 & 0 & 0 \\
\hline & Net requirements & & & & & 180 & & 320 & 400 & & 710 & 70 & & 45 \\
\hline & $\begin{array}{l}\text { Planned order } \\
\text { receipts }\end{array}$ & & & & & 180 & & 320 & 400 & & 710 & 70 & & 45 \\
\hline & $\begin{array}{l}\text { Planned order } \\
\text { released }\end{array}$ & & & 180 & & 320 & 400 & & 710 & 70 & & 45 & & \\
\hline \multirow{5}{*}{ G } & Gross requirements & & & 180 & & 460 & 400 & 320 & 1430 & 70 & 710 & 285 & & 70 \\
\hline & Projected on hand & 65 & 65 & 65 & 65 & 65 & 0 & 0 & 0 & 0 & 0 & 0 & 0 & 0 \\
\hline & Net requirements & & & 180 & & 395 & 400 & 320 & 1430 & 70 & 710 & 285 & & 70 \\
\hline & $\begin{array}{l}\text { Planned order } \\
\text { receipts }\end{array}$ & & & 180 & & 395 & 400 & 320 & 1430 & 70 & 710 & 285 & & 70 \\
\hline & $\begin{array}{l}\text { Planned order } \\
\text { released }\end{array}$ & & 180 & & 395 & 400 & 320 & 1430 & 70 & 710 & 285 & & 70 & \\
\hline \multirow{5}{*}{$\mathrm{H}$} & Gross requirements & & 180 & & 395 & 495 & 320 & 1610 & 270 & 710 & 640 & 35 & 70 & \\
\hline & Projected on hand & 80 & 80 & 80 & 80 & 80 & 0 & 0 & 0 & 0 & 0 & 0 & 0 & 0 \\
\hline & Net requirements & & 180 & & 395 & 415 & 320 & 1610 & 270 & 710 & 640 & 35 & 70 & \\
\hline & $\begin{array}{l}\text { Planned order } \\
\text { receipts }\end{array}$ & & 180 & & 395 & 415 & 320 & 1610 & 270 & 710 & 640 & 35 & 70 & \\
\hline & $\begin{array}{l}\text { Planned order } \\
\text { released }\end{array}$ & 180 & & 395 & 415 & 320 & 1610 & 270 & 710 & 640 & 35 & 70 & & \\
\hline
\end{tabular}

Tab. 5. Schedule for delivery of products I, J, K, L

\begin{tabular}{|c|c|c|c|c|c|c|c|c|c|c|c|c|c|c|}
\hline \multirow{2}{*}{ 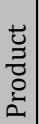 } & \multirow{2}{*}{ Specification } & \multicolumn{13}{|c|}{ Week } \\
\hline & & 1 & 2 & 3 & 4 & 5 & 6 & 7 & 8 & 9 & 10 & 11 & 12 & 13 \\
\hline \multirow{5}{*}{ I } & Gross requirements & & 360 & & 790 & 800 & 640 & 3160 & 140 & 1420 & 970 & & 140 & 45 \\
\hline & Projected on hand & 30 & 30 & 30 & 30 & 30 & 0 & 0 & 0 & 0 & 0 & 0 & 0 & 0 \\
\hline & Net requirements & & 360 & & 790 & 770 & 640 & 3160 & 140 & 1420 & 970 & & 140 & 45 \\
\hline & $\begin{array}{l}\text { Planned order } \\
\text { receipts }\end{array}$ & & 360 & & 790 & 770 & 640 & 3160 & 140 & 1420 & 970 & & 140 & 45 \\
\hline & $\begin{array}{l}\text { Planned order } \\
\text { released }\end{array}$ & 360 & & 790 & 770 & 640 & 3160 & 140 & 1420 & 970 & & 140 & 45 & \\
\hline $\mathrm{J}$ & Gross requirements & & 180 & & 395 & 400 & 320 & 1490 & 70 & 710 & 510 & & 70 & 30 \\
\hline
\end{tabular}




\begin{tabular}{|c|c|c|c|c|c|c|c|c|c|c|c|c|c|c|}
\hline \multirow{2}{*}{ 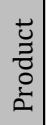 } & \multirow{2}{*}{ Specification } & \multicolumn{13}{|c|}{ Week } \\
\hline & & 1 & 2 & 3 & 4 & 5 & 6 & 7 & 8 & 9 & 10 & 11 & 12 & 13 \\
\hline & Projected on hand & 25 & 25 & 25 & 25 & 25 & 0 & 0 & 0 & 0 & 0 & 0 & 0 & 0 \\
\hline & Net requirements & & 180 & & 395 & 375 & 320 & 1490 & 70 & 710 & 510 & & 70 & 30 \\
\hline & $\begin{array}{l}\text { Planned order } \\
\text { receipts }\end{array}$ & & 180 & & 395 & 375 & 320 & 1490 & 70 & 710 & 510 & & 70 & 30 \\
\hline & \begin{tabular}{|l} 
Planned order \\
released
\end{tabular} & 180 & & 395 & 375 & 320 & 1490 & 70 & 710 & 510 & & 70 & 30 & \\
\hline \multirow{5}{*}{$\mathrm{K}$} & Gross requirements & & & 360 & & 830 & 800 & 180 & 2320 & 140 & 240 & 390 & & \\
\hline & Projected on hand & 0 & 0 & 0 & 0 & 0 & 0 & 0 & 0 & 0 & 0 & 0 & 0 & 0 \\
\hline & Net requirements & & & 360 & & 830 & 800 & 180 & 2320 & 140 & 240 & 390 & & \\
\hline & $\begin{array}{l}\text { Planned order } \\
\text { receipts }\end{array}$ & & & 360 & & 830 & 800 & 180 & 2320 & 140 & 240 & 390 & & \\
\hline & \begin{tabular}{|l}
$\begin{array}{l}\text { Planned order } \\
\text { released }\end{array}$ \\
\end{tabular} & & 360 & & 830 & 800 & 180 & 2320 & 140 & 240 & 390 & & & \\
\hline \multirow{5}{*}{$\mathrm{L}$} & Gross requirements & & & & & 350 & & 240 & 600 & & 320 & 105 & & \\
\hline & Projected on hand & 0 & 0 & 0 & 0 & 0 & 0 & 0 & 0 & 0 & 0 & 0 & 0 & 0 \\
\hline & Net requirements & & & & & 350 & & 240 & 600 & & 320 & 105 & & \\
\hline & $\begin{array}{l}\text { Planned order } \\
\text { receipts }\end{array}$ & & & & & 350 & & 240 & 600 & & 320 & 105 & & \\
\hline & $\begin{array}{l}\text { Planned order } \\
\text { released }\end{array}$ & & & & 350 & & 240 & 600 & & 320 & 105 & & & \\
\hline
\end{tabular}

\section{CONCLUSIONS}

The quality and correctness of the data used in its construction affect the effectiveness of the delivery schedule. Therefore, in order for the MRP system to function properly, all information resulting from the master production plan, regarding the state of the inventory held or the material structure of the product must be up to date and reviewed.

It should also be emphasized that both the simple MRP structure and its extended concepts (MRP II, CRP) are only tools, and the knowledge, skills and experience of people who use them depend on the effects that can be obtained for the company. Therefore, sometimes it is worth learning about the algorithms on which these systems are based, despite the IT systems created for the needs of the company, making calculations for all the company's resources. And this is also the purpose of this article. 


\section{REFERENCES}

[1] Barczak A., Florek J., Sydoruk T., Projektowanie zintegrowanych systemów informatycznych zarządzania, Publ. Akademia Podlaska, Siedlce 2006 [Designed of integrated computer management system — available in Polish].

[2] Bendkowski J., Radziejowska G., Logistyka zaopatrzenia w przedsiębiorstwie, Publ. Politechnika Śląska, Gliwice 2005 [Supply logistics in the company — available in Polish].

[3] Borucka A., Application of ARIMA Models for the Analysis of Utilization Process of Military Technical Objects, 'Logistyka i Transport', 2018, Vol. 37, No. 1, pp. 13-22.

[4] Borucka A., Forecasting of fire risk with regard to readiness of rescue and fire-fighting vehicles, 'Interdisciplinary Management Research XIV', Croatia, 2018, pp. 397-395.

[5] Borucka A., Funkcjonowanie wojskowych oddziałów gospodarczych $w$ nowym systemie logistycznym sił zbrojnych, 'Logistyka', 2013, No. 6, pp. 39-48 [Functioning of military economic units in the new armed forces logistics system — available in Polish].

[6] Borucka A., Markov models in the analysis of the operation process of transport means, Proceedings of the ICTTE International Journal for Traffic and Transport Engineering Conference, Belgrad, 2018, pp. 1073-1082.

[7] Borucka A., Model of the operation process of aircraft in the transport system, Proceedings of the ICTTE International Journal for Traffic and Transport Engineering Conference, Serbia, 2018, pp. 22-30.

[8] Borucka A., Risk Analysis of Accidents in Poland Based on ARIMA Model, 'Transport Means 2018', Proceedings of the 22nd International Scientific Conference, Part I, Lithuania, 2018, pp. 162-166.

[9] Borucka A., Three-state Markov model of using transport means, Proceedings of the 18th International Scientific Conference 'Business Logistics In Modern Management', Croatia, 2018, pp. 3-19.

[10] Bozarth C., Handfield R. B., Wprowadzenie do zarządzania operacjami i łańcuchem dostaw, OnePress, Helion, Gliwice 2007 [Introduction to operations and supply chain management available in Polish].

[11] Brzeziński M., Organizacja i sterowanie produkcja, Placet, Warszawa 2002 [Organization and control of production - available in Polish].

[12] Coyle J. J., Bardi E. J., Langley Jr C. J., Zarzqdzanie logistyczne, PWE, Warszawa 2002 [Logistics Management — available in Polish].

[13] Ficoń K., Logistyka ekonomiczna. Procesy logistyczne, BelStudio, Warszawa 2008 [Economical Logistics - available in Polish].

[14] Lysons K., Zakupy zaopatrzeniowe, PWE, Warszawa 2004 [Supply purchases — available in Polish].

[15] Mikosz B., Borucka A., Organizacja gospodarki odpadami w siłach zbrojnych na tle zmian militarnych i nowych wyzwań stawianych polskiej armii, 'Archiwum Gospodarki Odpadami i Ochrony Środowiska', 2008, No. 8, pp. 1-12 [Organization of waste management against the background of military changes posed to the Polish Army — available in Polish].

[16] Mitkow S., Borucka A., Mathematical model of travel times related to a transport congestion: an example of the capital city of Poland - Warsaw, Proceedings of the 18th International Scientific Conference 'Business Logistics In Modern Management', Croatia, 2018, pp. 501-526. 
[17] Świderski A., Borucka A., Mathematical Analysis of Factors Affecting the Road Safety in Selected Polish Region, 'Transport Means', Proceedings of the 22nd International Scientific Conference, Part II, Lithuania, 2018, pp. 651-654.

[18] Świderski A., Borucka A., Jacyna-Gołda I., Szczepański E., Wear of brake system components in various operating conditions of vehicle in the transport company, 'Eksploatacja i Niezawodność - Maintenance and Reliability', 2019, Vol. 21, No. 1, pp. 1-9.

[19] Świderski A., Borucka A., Skoczyński P., Characteristics and Assessment of the Road Safety Level in Poland with Multiple Regression Model, 'Transport Means', Proceedings of the 22nd International Scientific Conference, Part I, Lithuania, 2018, pp. 92-97.

[20] Wielgosik M., Borucka A., Istota i znaczenie służby przygotowawczej i szkolenia rezerw, 'Systemy Logistyczne Wojsk', 2016, No. 45, pp. 51-66 [The essence and importance of the preparatory and reserve training service - available in Polish].

\title{
WYBRANE ELEMENTY ZARZĄDZANIA PROCESAMI PRODUKCYJNYMI
}

\author{
STRESZCZENIE
}

Skuteczność i sprawność systemu produkcyjnego są gwarancją powodzenia przedsiębiorstwa, szczególnie w czasach dynamicznego rozwoju handlu (w tym internetowego) i coraz wyższych wymagań klientów, którzy chcą mieć towar zawsze dostępny i dostarczony najlepiej w dniu zamówienia. Nowoczesny odbiorca usług podnosi wysoko poprzeczkę nie tylko systemom produkcyjnym, ale także transportowym. Dlatego w firmach wdrażane są narzędzia informatyczne wspierające proces zarządzania wszystkimi obszarami ich działalności. W artykule scharakteryzowano wybrane sfery, skupiając się przede wszystkim na wsparciu procesu planowania produkcji.

Korzystanie z systemów informatycznych warto poprzedzić zgłębieniem wiedzy dotyczącej zastosowanych $\mathrm{w}$ nich algorytmów. W artykule przedstawiono więc przykład obliczeniowy wykorzystania procedury planowania zapotrzebowania materiałowego MRP dla złożonych wyrobów o strukturze modułowej, której celem jest wsparcie procesów planowania zapotrzebowania materiałowego i wykorzystania zasobów przedsiębiorstwa.

Słowa kluczowe:

planowanie produkcji, zarządzanie zasobami, planowanie potrzeb materiałowych, MRP.

$\begin{array}{ll}\text { Article history } \\ \text { Received: } & 10.01 .2019 \\ \text { Reviewed: } & 22.03 .2019 \\ \text { Revised: } & 30.03 .2019 \\ \text { Accepted: } & 30.03 .2019\end{array}$ 